\title{
First records of the bean-slug Sarasinula plebeia (Gastropoda: Veronicellidae) in Argentina
}

\author{
Eduardo Daniel Daglio ${ }^{1,4}$, Micaela de Lucía ${ }^{1,3,}$, Suzete Rodrigues Gomes ${ }^{2,6}$ \& Diego Eduardo Gutiérrez Gregoric ${ }^{1,3,7}$ \\ 1 Universidad Nacional de La Plata (UNLP), Facultad de Ciencias Naturales y Museo (FCNyM), División Zoología Invertebrados. \\ La Plata, Buenos Aires, Argentina. \\ ${ }^{2}$ Fundação Oswaldo Cruz (FIOCRUZ), Instituto Oswaldo Cruz (IOC), Laboratório de Referência Nacional para Esquistossomose - Malacologia. \\ Rio de Janeiro, RJ, Brasil. \\ ${ }^{3}$ Consejo Nacional de Investigaciones Científicas y Técnicas (CONICET). Buenos Aires, Buenos Aires, Argentina. \\ ${ }^{4}$ ORCID: http://orcid.org/0000-0001-7802-8650. E-mail: dagliodaniel@gmail.com \\ ${ }^{5}$ ORCID: http://orcid.org/0000-0002-8153-2716. E-mail: mec dl@hotmail.com \\ ${ }^{6}$ ORCID: http://orcid.org/0000-0002-5552-5053. E-mail: suzete.gomes@ioc.fiocruz.br \\ ${ }^{7}$ ORCID: http://orcid.org/0000-0002-8001-1062. E-mail: dieguty@fcnym.unlp.edu.ar (corresponding author)
}

\begin{abstract}
Sarasinula plebeia is a common land slug in tropical and subtropical areas, including South America. This species is known as Bean-slug but considered a pest of great importance in numerous crops, horticultural facilities, plant nurseries, and garden. Also, it is a natural host for nematodes that cause parasitosis in different countries. We report for the first time the occurrence of Sarasinula plebeia in Argentina, based on material collected in the provinces of Chaco and Misiones, extending the distribution of the species in South America to 34 terrestrial ecoregions.
\end{abstract}

Key-Words. Systellomatophora; Potential pest; Disease transmitter; Native species.

\section{INTRODUCTION}

Several species of the genus Sarasinula have been nominated for South America. However, in the reviews carried out by Thomé $(1989,1993)$, who studied the group for decades, he considered four possible valid species: S. linguaeformis (Semper, 1885), S. marginata (Semper, 1885), S. dubia (Semper, 1885) and S. plebeia (Fisher, 1868). Thomé (1989) also questioned the validity of S. dubia and S. marginata, which he considered a possible synonym of S. plebeia and S. linguaeformis, respectively. The main morphological difference between S. dubia and S. plebeia is found in the penis. In S. plebeia the penis is club-shaped, while in S. dubia it is tapered in the distal extremity (Thomé, 1989), which, however, can be considered a morphological variation in S. plebeia (Gomes \& Thomé, 2001, 2002). Further research by other authors already considered these species synonyms (Mansur \& Thomé, 1994; Rueda et al., 2002; Naranjo-García et al., 2007; Molet, 2014; Oliveira Rocha, 2019).

Sarasinula linguaeformis (= S. marginata) was described for Guayaquil, Ecuador (S. marginata for Rio de Janeiro, Brazil) and is currently reported in the following countries in South America: Guyana, Colombia, Ecuador, Peru, Paraguay, Argentina, and
Brazil where is considered a native species (Thomé, 1993; Santin \& Miquel, 2015; Oliveira Rocha, 2019).

Darrigran et al. (2020) considered Sarasinula plebeia (= S. dubia) as cryptogenic in South America since this species was described for New Caledonia (Oceania). However, Vaginula behni Semper, 1885, that is currently a synonym for S. plebeia according to Thomé (1993), was originally described based on material from Rio de Janeiro, Brazil, what indicates that it is present for a long time in South America as well. Besides, the other species of the genus is also found in America and Sarasinula has relationships with other American genera (Dayrat et al., 2011), supporting the American origin hypothesis for S. plebeia, as postulated by Cowie et al. (2008). Currently, S. plebeia is registered in South America in the following countries: Brazil (since 1885), Colombia (1978), Venezuela (1992), Chile (1993, without specifying location), Ecuador (2008) and Peru (2015) (Thomé, 1993; Darrigran et al., 2020). Besides, it is registered in several regions, in which is considered non-native or invasive as North and Central America, the West Indies, Asia, Africa, Australia, Fiji, Hawaii, Indonesia, Marianas, New Caledonia, Philippines, Solomon Ids, Tahiti, Tuamotu, Vanuatu, Western Samoa West Islands (Thomé, 1993; Gomes \& Thomé, 2004; GBIF, 2020). 
Sarasinula plebeia has been reported as an intermediate host of health-important nematodes such as Angiostrongylus costaricensis Morera \& Céspedes, 1971 (in Central America) that cause abdominal angiostrongyliasis, and the rat lungworm, Angiostrongylus cantonensis (Chen, 1935), which is the etiologic agent of eosinophilic meningitis (in Pacific Islands) (Robinson \& Hollingsworth, 2004). This species is known as Bean-slug and considered a pest of great importance in numerous crops, horticultural facilities, plant nurseries, and gardens (Rueda et al., 2002; Naranjo-García et al., 2007; Constantino et al., 2010).

This work aims to report for the first time the occurrence of Sarasinula plebeia in Argentina, based on material collected in the provinces of Chaco and Misiones.

\section{MATERIAL AND METHODS}

The slugs were obtained by manual collection by Gutiérrez Gregoric in 2000 and 2011. The collected specimens were relaxed in menthol solution for one day, to be later preserved in ethanol (material of the year 2000) and Raillet-Henry solution (material of the year 2011) and deposited in the Malacological Collection at the La Plata Museum (MLP-Ma) of the La Plata National University, Buenos Aires Province, Argentina. The identification of the material was carried out following Thomé (1971) and Gomes \& Thomé (2001, 2002). For the synonymous list, the work carried out by Thomé $(1989,1993)$ for America and Gomes \& Thomé (2004) for the Australian region was taken as a basis.

Due to the collection time of the material from the province of Chaco (2000), and the type of conservation of the material from Misiones (Raillet-Henry solution), it was not possible to extract DNA from the samples.

\section{RESULTS}

\section{Sarasinula plebeia (Fischer, 1868)}

Vaginulus plebeius Fischer, 1868: 145-146; Thomé, 1971: 34-36.

Vaginula andreana Semper, 1885: 321.

Vaginula behnii Semper, 1885: 310-311.

Vaginula dubia Semper, 1885: 296; Thomé, 1972: 252-253. Veronicella hedleyi Simroth, 1889: 552; Simroth, 1891: 863-906; Simroth, 1918: 281-292.

Vaginula levucana Simroth, 1918: 262-290.

Vaginula samoana Simroth, 1918: 290-291.

Vaginula tahitiana Simroth, 1918: 290-292.

Sarasinula plebeja Grimpe \& Hoffmann, 1924: 177; Grimpe \& Hoffmann, 1925a: 19-26; Grimpe \& Hoffmann, 1925b: 357-362; Hoffmann, 1925: 190, 251-252; Thomé, 1975: 25-27.

Imerinia plebeja Baker, 1925; Hoffmann, 1934: 259-260.

Veronicela discrepans Thiele, 1927: 328.

Sarasinula lemei Thomé, 1967: 528-531.

Vaginulus (Sarasinula) plebeius Forcart, 1969: 149-150;

Aguayo, 1964; Forcart, 1973; Cowie, 1998.
Sarasinula dubia Thomé, 1993: 71; Thomé et al., 1997: 530; Simone, 2006: 96; Agudo-Padrón, 2008: 153.

Vaginula plebeia Cowie, 1997: 38.

Sarasinula plebeia Thomé, 1975: 25-27; Thomé, 1989: 19-23; Thomé, 1993: 71; Thomé et al., 1997: 530; Gomes \& Thomé, 2001: 141-143; Gomes \& Thomé, 2002; Gomes \& Thomé, 2004: 591; Simone, 2006: 97; Agudo-Padrón, 2008: 153.

Material examined: Puerto Iguazú, Misiones province

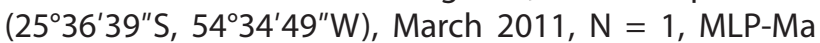
15015; Selvas del Río de Oro, Chaco province $\left(26^{\circ} 45^{\prime} 09^{\prime \prime} S\right.$, $58^{\circ} 58^{\prime} 30^{\prime \prime}$ W), July 2000, N = 1, MLP-Ma 15016.

Description (Fig. 1): Thickened notum that sometimes appears dotted (Fig. 1A); light brown to dark coloration without pale stripes. The tentacles are contracted and hidden underneath the notum when the slug is dormant. Penis (Fig. 1C) short, smooth, without annular protrusion, bilaterally symmetrical, with an enlarged glans. There is no spatha. Digitiform gland (= penial gland, Fig. 1B) with an elongated papilla with 6 short tubules with varying lengths (not bifurcate). Proximal region of the tubules meandering and covered by a thick membrane. The width to length ratio of the papilla is 2.33 , and the width to length ratio of the glans is 1.52. Copulation bursa (or spermatheca) formed by a globular and thin sac seated over a thick cylindrical uniform duct, which narrows slightly until it penetrates the integument, where it joins the oviduct, opening in the female genital pore. Canalis junctor (or junctor duct) thin and short, penetrating the narrowest part of the copulation bursa itself. The rectum penetrates the integument near the female genital pore, located near the middle of the right hyponotum. The two nerve pairs, pedal and pallial, originate in their respective ganglia in the periesophageal ring and stretch through the body cavity in two sets, right and left, which runs together from the nerve ganglion to the posterior end of the body, centrally along the foot. The pairs leave a small anterior space for the passage of the main artery (fide Grimpe \& Hoffmann, 1925b).

Ecological notes: Both new records were found in residential gardens, under branches and trunks, so it is inferred that the trade-in plants are the pathway of dispersal of this species. The Selvas del Río de Oro locality corresponds to the Humid Chaco terrestrial ecoregion (humid temperate climate), while Puerto Iguazú locality corresponds to the Alto Paraná Atlantic Forest ecoregion (subtropical climate), ecoregions defined by Olson \& Dinerstein (2002). Both records are the first to be cited for these terrestrial ecoregions (Fig. 2).

Distribution in South America (Fig. 2): Argentina: Misiones and Chaco provinces (This study). Brazil: States of Rio Grande do Sul, Santa Catarina, São Paulo, Rio de Janeiro, Espírito Santo, Bahia, Pará (Santarém), Paraíba, and Ceará (Thomé, 1993; Mansur \& Thomé, 1994; Thomé et al., 1997; Simone, 2006; Agudo-Padrón, 2008; GBIF, 2020). Colombia: Departments of Risaralda (Pereira), 


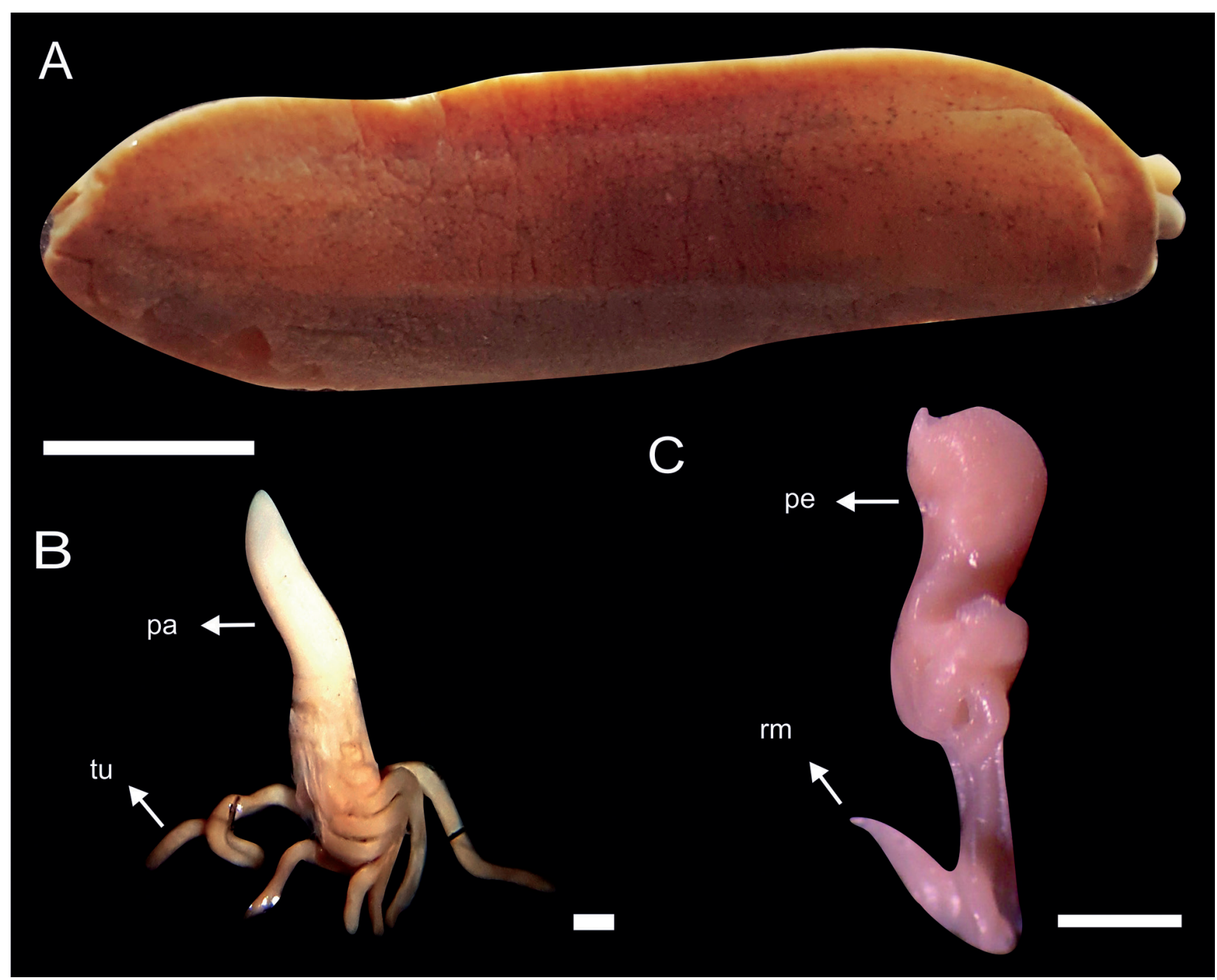

Figure 1. Sarasinula plebeia for Misiones province (MLP-Ma 15015). (A) Dorsal view; (B-C) part of male genitalia; (B) digitiform gland; (C) penis. pe = penis; pa = papilla of the digitiform gland; $r m=$ penis retractor muscle; tu = tubules. Scale bar: $A=1 \mathrm{~cm} ; B$ and $C: 1 \mathrm{~mm}$.

Atlantico (Barranquilla), Valle del Cauca (Palmira) Antioquía (San Nicolas Valley), and Caldas. (Götting, 1978; GBIF, 2020). Andina región (Constantino et al., 2010). Ecuador: Provinces of Zamora and Pichincha (GBIF, 2020). Peru: Departments of Lambayeque and Loreto (Iquitos) (GBIF, 2020). Venezuela: States of Anzoátegui (San Tome), Aragua, Caracas (Campo Alegre), Mérida, Miranda (EI Hatillo), Monagas, Sucre, and Táchira, (Fernández de Varela, 1982; Thomé et al., 1997; GBIF, 2020).

\section{DISCUSSION}

For Argentina, eight species of Veronicellidae are registered according to Santin \& Miquel (2015). In their review, Sarasinula linguaeformis is cited for Argentina, in the provinces of Tucumán, Corrientes, and Misiones (Puerto Iguazú city), while Sarasinula plebeia has no records in Argentina. Mansur \& Thomé (1994) examined Sarasinula specimens of Corrientes (Argentina), but they do not specify if they were S. plebeia or S. linguaeformis.

There are no studies in South America that relate the internal anatomy of the different populations of this species. However, the measurements taken in the male genital system of the specimens studied here (width to length ratio of the penial papilla and width of glans) are according to the those mentioned for the non-Australian specimens (Gomes \& Thomé, 2002).

With this new record in the Misiones, there are now seven species of Veronicellidae in this province: Angustipes difficilis (Colosi, 1921), Phyllocaulis soleiformis (d'Orbigny, 1835), P. variegatus (Semper, 1885), P. tuberculosus (Martens, 1868), Latipes erinaceus (Colosi, 1921), that Oliveira Rocha \& D'ávila (2019) recently included in Angustipes genus, Sarasinula linguaeformis, and S. plebeia. In turn, in the Puerto Iguazú city, six of these species are registered ( $P$. tuberculosus is absent), and the two Sarasinula species coexist. Santin \& Miquel (2015) cited Angustipes difficilis and Phyllocaulis soleiformis in Chaco province. There are no previous records for Selvas de Rio de Oro.

Only two specimens of S. plebeia have been registered in Argentina since no new sampling has been carried out at both sites since then. However, the occurrence in two different ecoregions indicates that their presence in Argentina is possibly due to different events. 


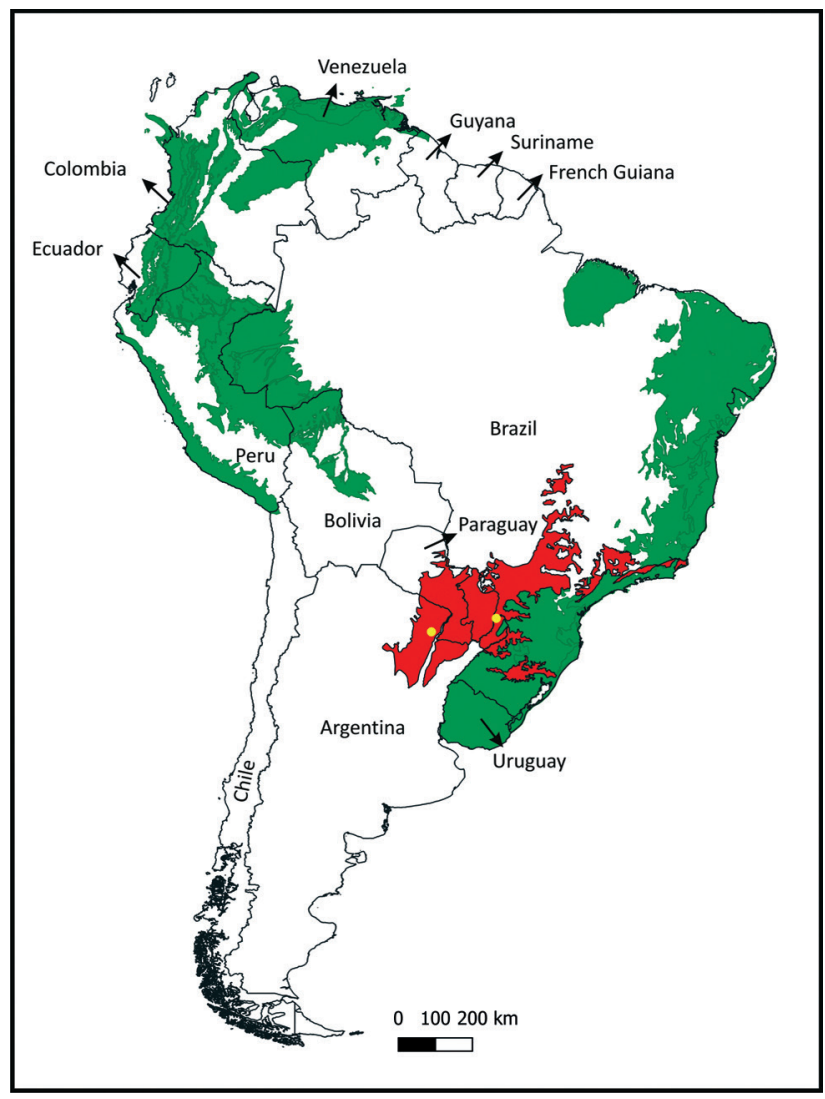

Figure 2. Distribution of S. plebeia in South America. Green: ecoregions where S. plebeia is recorded according to Darrigran et al. (2020) and bibliography (see Distribution in the text). Red: new ecoregions with S. plebeia. Yellow circles: new records for Argentina.

Since S. plebeia is considered to have a neotropical origin as mentioned by Cowie et al. (2008), the presence in Argentina, surely due to human activity, is within its potential distribution. For this reason, the presence in Argentina can be considered as a "Transplant of species" as defined by Pérez et al. (2007). The nearest records of S. plebeia to Argentina were reported for the Brazilian states of Rio Grande do Sul and Santa Catarina (Mansur \&Thomé, 1994; Simone, 2006; Agudo-Padrón et al., 2013; Gomes et al., 2013), both bordering on the province of Misiones and corresponding to the terrestrial ecoregions of Araucaria Moist Forests and Uruguayan Savanna. According to Darrigran et al. (2020), and the distribution here presented, this species is present in 32 terrestrial ecoregions of South America. The new records correspond to two new ecoregions so that this entity is now registered in at least 34 ecoregions out of a total of 109 in South America.

The new records in Argentina belong to two new ecoregions for this species, which not only covers Argentina but also regions of Paraguay and Brazil. Given that the environmental conditions in each ecoregion are similar (e.g., climate, geomorphology, soil, hydrology) this species could potentially be registered in Paraguay.

Puerto Iguazú city has been affected since 2010 by the presence of the African giant snail Achatina fulica Bowdich, 1822 and other invasive gastropods such as Bradybaena similaris (Férussac, 1822) and Meghimatium pictum (Stoliczka, 1873) (Gutiérrez Gregoric et al., 2011, $2013 a, b)$. There are currently 30 non-native species of land gastropods in Argentina, mostly in the North and Northeast regions (Darrigran et al., 2020). The presence of non-native, invasive, or transplanted species increases the transmission of parasitosis in this area, in addition to incorporating a new potential crop pest.

\section{REFERENCES}

Aguayo, C.G. 1964. Notas sobre la distribución de la babosa Vaginulus plebejus, Mollusca: Veronicellidae. Caribbean Journal of Science, 4(4): 549-551.

Agudo-Padrón, A.I. 2008. Listagem sistemática dos moluscos continentais ocorrentes no Estado de Santa Catarina, Brasil. Comunicaciones de la Sociedad Malacológica del Uruguay, 9(91): 147-179.

Agudo-Padrón, A.I. \& Saalfeld, K. 2013. Moluscos e Saúde Pública em Santa Catarina: subsídios para a formulação estadual de políticas preventivas sanitaristas. Duque de Caxias,RJ, Espaço Científico Livre Projetos Editoriais. $132 \mathrm{pp}$.

Baker, H.B. 1925. Nomenclature of Veronicellidae (Vaginulidae). Nautilus, 39(1): 13-18.

Constantino, L.M.; Gomes, S. \& Benavides, P. 2010. Descripción y daños causados por las babosas Colosius pulcher y Sarasinula plebeia en el cultivo del café en Colombia. Avances Técnicos Cenicafé, 392: 1-8.

Cowie, R.H. 1997. Catalog and bibliography of the nonindigenous nonmarine snails and slugs of the Hawaiian Islands. Bishop Museum Occasional Papers, 50: 1-66.

Cowie, R.H. 1998. Catalog of the Nonmarine snails and slugs of the Samoan Islands. Bishop Museum Bulletins in Zoology, 3: 1-122.

Cowie, R.H.; Hayes, K.A.; Tran, C.T. \& Meyer, W.M. 2008. The horticultural industry as a vector of alien snails and slugs: Widespread invasions in Hawaii. International Journal of Pest Management, 54: 267-276.

Darrigran, G.; Agudo-Padrón, A.I.; Baez, P.; Belz, C.; Cardoso, F.; Carranza, A.; Collado, G.; Correoso, M.; Cuezzo, M.G.; Fabres, A.; Gutiérrez Gregoric, D.E.; Letelier, S.; Ludwig, S.; Mansur, M.C.; Pastorino, G.; Penchaszadeh, P.E.; Peralta, C; Rebolledo, A.; Rumi, A.; Santos, S.; Thiengo, S.; Vidigal, T. \& Damborenea, C. 2020. Non-native South American mollusks: Prelude to an exotic ecosystem? Biological Invasions, 22(3): 853-871.

Dayrat, B.; Conrad, M.; Balayan, S.; White, T.R.; Albrecht, C.; Golding, R.; Gomes, S.R.; Harasewych, M.G. \& de Frias Martins, A.M. 2011. Phylogenetic relationships and evolution of pulmonate gastropods (Mollusca): new insights from increased taxon sampling. Molecular Phylogenetics and Evolution, 59(2): 425-437.

Fernández de Varela, J. 1982. Contribución al conocimiento de las babosas y sietecueros (Mollusca: Gastropoda) que causan daños a la agricultura en Venezuela. Revista de la Facultad de Agronomía, Maracay, 7: 353-386.

Fischer, P. 1868. Diagnoses de deux Limaciens de la Nouvelle Calédonie. Journal de Conchyliologie, 16: 145-146.

Forcart, L. 1969. Veronicellid land slugs from the New Hebrides, with description of Semperula solemi, new species. Fieldiana: Zoology, 51(12): 147-156.

Forcart, L. 1973. Notes on Veronicellidae and Athoracophoridae in Field Museum of Natural History, Chicago. Nautilus, 87(1): 25-27.

Global Biodiversity Information Facility (GBIF). 2020. Sarasinula plebeia (P. Fischer, 1868). In: Miller, S.E. \& Rycroft S. Terrestrial Slugs Web. Scratchpads. Available at: http://doi.org/10.15468/jilt4h. Access in: 09/03/2020.

Gomes, S.R. \& Thomé, J.W. 2001. Anatomia comparada de cinco espécies da família Veronicellidae (Gastropoda, Soleolifera) ocorrentes nas regiões Australiana e Oriental. Biociências, Porto Alegre, 9(2): 137-151. 
Gomes, S.R. \& Thomé, J.W. 2002. Variabilidade morfológica de Sarasinula plebeia (Fischer, 1868) (Gastropoda, Veronicellidae) na região biogeográfica australiana. Acta Biológica Leopoldensia, 24: 37-46.

Gomes, S.R. \& Thomé, J.W. 2004. Diversity and distribution of the Veronicellidae (Gastropoda, Soleolifera) in the Oriental and Australian biogeographical regions. Memoirs of the Queensland Museum, 49(2): 589-601.

Gomes, S.R.; Robinson, D.G.; Zimmerman, F.J; Obregón, 0. \& Barr, N.B. 2013. Morphological and molecular analysis of the Andean slugs Colosius confuses, n. sp., a newly recognized pest of cultivated flowers and coffee from Colombia, Ecuador and Peru, and Colosius pulcher (Colosi, 1921) (Gastropoda, Veronicellidae). Malacologia, 56: 1-31.

Götting, K.J. 1978. Lista preliminar de los caracoles terrestres de la región septentrional de Colombia. Anales Del Instituto de Investigaciones Marinas de Punta de Betín, 10: 101-110.

Grimpe, G. \& Hoffmann H. 1924. Diagnosen neuer Athoracophoriden (Gastropoda, Pulmonata). Zoologische Anzeiger, 58: 171-177.

Grimpe, G. \& Hoffmann H. 1925a. Versuch einer Revision der indischen, indound polynesischen Vaginuliden (Gastrop Pulm.). Zeitschrift fur Wissenschaftliche Zoologie, 124(1): 1-50.

Grimpe, G. \& Hoffmann H. 1925b. Die Nacktschnecken von Neu-Caledonien, den Loyalty-Inseln und den Neuen-Hebriden. Nova Caledonia, Series A, Zoologie, 3(10): 339-476.

Gutiérrez Gregoric, D.E.; Beltramino, A.; Vogler, R.E.; Cuezzo, M.G.; Núñez, V.; Gomes, S.R.; Virgillito, M. \& Miquel, S.E. 2013b. First records of four exotic slugs in Argentina. American Malacological Bulletin, 31(2): 245-256.

Gutiérrez Gregoric, D.E.; Núñez, V.; Vogler, R.E. \& Rumi, A. 2011. Invasion of the Argentinean Paranense rainforest by giant African snail, Achatina fulica. American Malacological Bulletin, 29(1-2): 135-137.

Gutiérrez Gregoric, D.E.; Núñez, V.; Vogler, R.E.; Beltramino, A. \& Rumi, A. 2013a. Gasterópodos terrestres de la provincia de Misiones, Argentina. Revista de Biología Tropical, 61(4): 1759-1768.

Hoffmann, H. 1925. Die Vaginuliden. Ein Beitrag zur Kenntnis ihre Biologie, Anatomie, Systematik, geographischen Verbreitung und Phylogenie. Jenaische Zeitschrift für Naturwissenschaft, 61(1/2): 1-374.

Hoffmann, H. 1934. Nacktschnecken und Halbnacktschnecken von Java und Sumatra. Archiv für Hydrobiologie, Stuttgart, Supplment, 13(2): 255-291.

Mansur, G. \& Thomé, J.W. 1994. Contribuição à biología de Sarasinula linguaeformis (Semper, 1885) e Sarasinula plebeia (Fischer, 1868) (Veronicellidae, Gastropoda). Biociências, Porto Alegre, 2(2): 39-47.

Molet, T. 2014. CPHST Pest Datasheet for Sarasinula spp. USDA-APHIS-PPQ-CPHST. Available at: http://download.ceris.purdue. edu/file/2558. Access in: 02/06/2020.

Naranjo-García, E.; Thomé, J.W. \& Castillejo, J. 2007. A review of the Veronicellidae from Mexico (Gastropoda: Soleolifera). Revista Mexicana de Biodiversidad, 78: 41-50.

Oliveira Rocha, C.A. 2019. Estratégia de história de vida e recaracterizaçao morfológica Sarasinula linguaeformis (Semper, 1885) (Eupulmonata, Veronicellidae). (Masters Dissertation). Universidade Federal de Juiz de Fora, Juiz de Fora.

Oliveira Rocha, C.A. \& D'ávila, S. 2019. New morphological characterization of Latipes erinaceus (Gastropoda, Veronicellidae), differential diagnosis for the genera Angustipes and Latipes, and novel combinations for species of Latipes. Zoological Science, Tokyo, 36(3): 231-241.
Olson, D.M. \& Dinerstein, D. 2002. The Global 200: Priority ecoregions for global conservation. Annals of the Missouri Botanical Garden, 89: 125-126.

Pérez, J.E.; Alfonsi, C.; Salazar, S.K.; Macsotay, 0.; Barrios, J. \& Martinez Escarbassiere, R. 2007. Especies marinas exóticas y criptogénicas en las Costas de Venezuela. Boletin del Instituto Oceanográfico de Venezuela, 46 : 79-96.

Robinson, D.G. \& Hollingsworth, R.G. 2004. Survey of slug and snail pests on subsistence and garden crops in the islands of the American Pacific: Guam, and the Northern Mariana islands. Part I. The leatherleaf slugs (family: Veronicellidae). Washington, DC, USDA.

Rueda, A.; Caballero, R.; Kamnsky, R. \& Andrews, K.L. 2002. Vaginulidae in Central America, with emphasis on the bean slug Sarasinula plebeia (Fischer). In: Barker, G.M. (Ed.). Molluscs as Crop Pests. Wallingford, U.K., CABI Publishing. p. 115-144.

Santin, R.A. \& Miquel, S.E. 2015. Veronicellidae in Argentina: taxonomy, morphologyand distribution (Mollusca:Gastropoda:Systellomatophora). Archiv für Molluskenkunde, 144(2): 105-123.

Semper, C. 1885. Landmollusken. In: Reisen im Archipel der Philippinen. Wiesbaden, C.W. Kreidel's. p. 291-327.

Simone, L.R.L.D. 2006. Land and freshwater Mollusks of Brazil. São Paulo, EGB, FAPESP. 390p.

Simroth, H. 1889. Ueber einige Vaginula-Arten. (Vorlaeufige Mittheilung). Zoologischer Anzeiger, 12: 551-556.

Simroth, H. 1891. Ueber einige Vaginula-Arten. Zoologischer Anzeiger, 5: 861-906.

Simroth, H. 1918. Über einige Nacktschnecken vom Malayischen Archipel von Lombok an ostwaerts bis zu den Gesellschafts-Inseln. Abhandlungen der Senckenbergischen Naturforschenden Gesellschaft, 35: 261-306.

Thiele, J. 1927. Ueber einige brasilianische Landschnecken. Abhandlungen der Senckenbergischen Naturforschenden Gesellschaft, 40: 307-329.

Thomé, J.W. 1967. A ocorrência de Veronicellidae na Amazonia brasileira, com descrição de duas espécies novas (Soleolifera, Gastropoda). In: Lent, H. (Ed.). Atas do Simpósio da Biota Amazônica. Rio de Janeiro, Conselho Nacional de Pesquisas. v.5, p. 521-532.

Thomé, J.W. 1971. Redescrição dos tipos de Veronicellidae (Mollusca, Gastropoda) neotropicais: VII espécies depositadas no Muséum National d'Histoire Naturelle, Paris, França. Iheringia (Zool.), 40: 27-52.

Thomé, J.W. 1972. Redescrição dos tipos de Veronicellidae (Mollusca; Gastropoda) Neotropicais. VIII. Espécies depositadas no "Institut fiir Spezielle Zoologie und Zoologisches Museum" de Berlim. Arquivos de Zoologia, São Paulo, 21(5): 235-281.

Thomé, J.W. 1975. Os gêneros da família Veronicellidae nas Américas (Mollusca; Gastropoda). Iheringia (Zool.), 48: 3-56.

Thomé, J.W. 1989. Annotated and illustrated preliminary list of the Veronicellidae (Mollusca: Gastropoda) of the Antilles, and Central and North America. Journal of Medical and Applied Malacology, 1: 11-28.

Thomé, J.W. 1993. Estado atual da sistemática dos Veronicellidae (Mollusca; Gastropoda) americanos com comentários sobre sua importância econômica, ambiental e na saúde. Biociências, Porto Alegre, 1: 61-75.

Thomé, J.W.; dos Santos, P.H.\& Pedott, L. 1997. Annotated list of Veronicellidae from the collections of the Academy of Natural Sciences of Philadelphia and the National Museum of Natural History, Smithsonian Institution, Washington, DC, USA (Mollusca: Gastropoda: Soleolifera). Proceedings of the Biological Society of Washington, 110(4): 520-536. 